\title{
Sediment Characteristics and Benthos Community Spread in Lake Beratan in Bali
}

\author{
Dewa Made Atmaja \\ Sebelas Maret University \\ Solo City, Indonesia \\ MTh. Sri Budiastuti \\ Sebelas Maret University \\ Solo City, Indonesia \\ Prabang Setyono \\ Sebelas Maret University \\ Solo City, Indonesia \\ Sunarto \\ Sebelas Maret University \\ Solo City, Indonesia
}

Coresponding email: atmajadewamade@yahoo.com

\begin{abstract}
Lake Beratan is now under a high pressure of both natural and nonnatural processes, having a high level of sedimentation, domestic waste pollution and substantial fish farming using floating baskets (karamba jaring apung/KJA).Changes that are taking place in Lake Beratan environment which are caused by sedimentation will have a real impact on benthos community. This study was aimed to evaluating sediment characteristics in Lake Beratan and identify benthos community spread. This study used a descriptive quantitative approach with a survey method in which 6 lake water samples were selected. The parameters of water quality measured were dissolved oxygen content, temperature, turbidity, conductivity, $\mathrm{pH}$, and total organic matter. The lake sediment characteristics were determined based on total organic matter grain fraction and their organic $\mathrm{C} / \mathrm{N}$ ratio. The quality of Lake Beratan water shows a $\mathrm{pH}$ that tends to be based, turbidity ranges from low to high, and the total organic matter is relatively high. The characteristics of the sediment are dominated by silt and clay fractions, with the total organic matter content ranging from 12.6 to $19.6 \%$, and their organic $\mathrm{C} / \mathrm{N}$ ratio is relatively low $(<20)$. Eleven benthos organism varieties were found consisting of Oligochaeta, Diptera and Mollusca with the abundances ranging from 284 to- $-3409 \mathrm{ind} / \mathrm{m}^{2}$. The presence of Tubificid and surface Chironomid dominated benthos community parallel to their high total organic matter in Lake Beratan sediment.
\end{abstract}

Keywords-Lake Beratan, sediment characteristics, total organic matter benthos community

\section{INTRODUCTION}

The significance of Lake Beratan lies in its two allocations namely as a hydrological system chain and as one of the sources of revenue for Tabanan second level local government. Its function as a hydrological system chain is very important, because it functions as rain water reservoir. Economically, it functions as a water resource for the community surrounding the lake for drinking, fishery and tourist object. An increase in economic activity, both in the industrial and agricultural sectors have caused some problems such as the damage of the water system region, the environmental pollution, erosion, and the silting up of the lake because of sediment inflow (Arsyad, 2012; Walter et al. 2014).

Lake Beratan is now under a heavy pressure from a highlevel sedimentation, domestic waste pollution, and the rather quick growth of fish farming using floating baskets (karamba jaring apung/KJA) (Hehanussa, 2005). Based on Quickbird satellite image analysis result in 2005 the water surface area of Lake Beratan was $3.827 \mathrm{~km}^{2}$ while it had become 3.764 $\mathrm{km}^{2}$ in 2014 . In the 9 years period, there had been a $0.063 \mathrm{~km}^{2}$ decrease $(1.65 \%)$ of the lake area and automatically it had reduced the lake water volume because of the sedimentation.

The damage of Lake Beratan waters has not only been due to the activities of the community in the lake vicinity, but it has also been due to the natural condition or climate such as high rainfall that has caused erosion in the catchment area and finally surface flow enters Lake Beratan carrying sediment material and organic matter from domestic waste (Adnyana, 2013). The accumulation of the organic matter from the domestic waste and the activities of fish farming using floating baskets in the sediments will cause anerobic condition, which directly has an effect on benthos community. 
The spread of benthos community is influenced by the water quality condition, bottom sediment, the abundance and spread of water plants. Then, the effect of the accumulation of the organic matter in the sediment causes a disturbance to the life of bottom fish and the food chain system of the fish that feeds on benthos community. Benthos community in Lake Beratan is the important component of the water ecosystem. The importance of benthos community is due to its function as food chain and at the same time it is the source of feed for carnivore fish.This study was aimed to evaluate the sediment characteristics in Lake Beratan and identifying the spread of benthos community.

\section{METHOD}

The study was conducted in Lake Beratan of Tabanan Regency, Bali in February 2015. The location of sampling spread in six observation points. The water characteristics of Lake Beratan was evaluated from the parameters of dissolved oxygen, temperature, turbidity, conductivity, $\mathrm{pH}$ and total organic matter. The content of dissolved oxygen was measured by DO meter YSI, temperature, turbidity, conductivity and $\mathrm{pH}$ were measured by WQC (Water Quality Checker), TOM (Total Organic Matter) of the water using titrimetry method (Greenberg et al., 1992).

The characteristics of the lake sediment were determined according to the grain fraction of its total organic matter and its organic $\mathrm{C} / \mathrm{N}$ ratio. To analyze the sediment grain fraction stratified filter and pipette method (Hesse, 1971) were used. The content of the total organic matter in the sediment was determined gravimetrically by turning it into dust at 550\% using muffle furnace (Buchanan et al., 1984). To find out the $\mathrm{C} / \mathrm{N}$ organic ratio colonimetry and Kurmis method were used (Hidayat, 1988).

The sampling of the sediment and benthos was done by using Ekman grab. The bottom sediment was filtered using a 1 $\mathrm{mm}$ diameter filter, benthos organism that had been preserved in formalin solution $(10 \%)$. Benthos was identified by using Pennak criterion (1978).

\section{FINDING AND DISCUSSION}

\section{A. Lake Beratan Water Quality}

The quality of Lake Beratan water shows a normal temperature range, $\mathrm{pH}$ that tends to be base, turbidity at the observation points is high, conductivity is still below the water quality standard the dissolved oxygen at all observation points is low and the total organic matter content is relatively high (> $300 \mathrm{mg} / \mathrm{l})$. For further information see Table 1 below.
TABLE 1. CONDITIONS OF SOME PARAMETERS OF LAKE BERATAN WATER QUALITY

\begin{tabular}{cccc}
\hline $\begin{array}{c}\text { Obser- } \\
\text { vation point }\end{array}$ & $\begin{array}{c}\text { Temperature } \\
\left({ }^{0} \mathrm{C}\right)\end{array}$ & $\mathrm{pH}$ & $\begin{array}{c}\text { Turbidity } \\
(\mathrm{NTU})\end{array}$ \\
\hline 1 & 27.1 & $7\urcorner 2$ & 94 \\
2 & 27.3 & 7.6 & 74 \\
3 & 27.5 & 8.2 & 30 \\
4 & 28.2 & 8.4 & 20 \\
5 & 27.5 & 7.7 & 2 \\
6 & 27.6 & 7.1 & 2 \\
\hline \multicolumn{5}{c}{} & & $\mathrm{TOM}$ \\
Obser- & $\mathrm{DHL}$ & $\mathrm{DO}$ & $(\mathrm{mg} / \mathrm{l})$ \\
\hline 1 & $(\mu \mathrm{mhos} / \mathrm{cm})$ & 4.5 & 360.4 \\
2 & 67 & 3.6 & 400.9 \\
3 & 50 & 4.8 & 410.8 \\
4 & 65 & 5.1 & 420.9 \\
5 & 47 & 5.3 & 320.8 \\
6 & 46 & 5.4 & 310.9 \\
\hline
\end{tabular}

The $\mathrm{pH}$ of the lake water tends to be base $(\mathrm{pH}>7.0)$ reflecting the condition of the catchment area of Lake Beratan in the form of volcanic rock formation. The rate of turbidity of the water is often ecologically ignored, such as in water quality standard for water quality management and pollution control, the effect on fish community and macro-benthos community. When viewed from clean water quality standard ( $\leq 25$ NTU) (The Republic of Indonesia Minister of Health Regulation No. 416/IX/90), the turbidity of samples 1, 2, and 3 shows a high condition. The high turbidity in sample 1 reaches $94 \mathrm{NTU}$, especially due to shallow waters $\quad(<0.5$ meter) and at the time of measurement the condition of the wavy water made very intensive sediment mixing process possible. The turbidity of sample 6 seems to support the highest conductivity.

The content of total organic matter (TOM) in the lake waters is high enough (> $300 \mathrm{mg} / \mathrm{l})$ and is the same in all over the lake, seems to be supported by the high total organic matter supply from the river.

\section{B. Sediment Characteristics}

The result of laboratory analysis shows that the sediment fraction in Lake Beratan is dominated by sand, silt and clay fractions. Samples 2, 3 and 4 contain $>70 \%$ (high) sand fraction. Samples 2, 3 and 4 form the mainstream in the lake so that there is a sediment accumulation, marked also by very hard bottom substrate. While samples 5 and 6 are not the mainstream and have $>30 \%$ clay fraction, and samples 1 and 6 contain high silt fraction $(>41 \%)$. For more information see Table 2 below. 
TABLE 2. SEDIMENT CHARACTERISTICS OF LAKE BERATAN

\begin{tabular}{|c|c|c|c|}
\hline \multirow{2}{*}{$\begin{array}{c}\text { Obser- } \\
\text { vation Points }\end{array}$} & \multicolumn{2}{|c|}{ Material } & Organic \\
\hline & \multicolumn{2}{|c|}{ TOM (\% dry weight) } & C / N Ratio \\
\hline 1 & \multicolumn{2}{|c|}{16.5} & 11 \\
\hline 2 & \multicolumn{2}{|c|}{15.8} & 14 \\
\hline 3 & \multicolumn{2}{|c|}{19.6} & 15 \\
\hline 4 & \multicolumn{2}{|c|}{15.4} & 17 \\
\hline 5 & \multicolumn{2}{|c|}{12.7} & 15 \\
\hline 6 & \multicolumn{2}{|c|}{12.6} & 12 \\
\hline \multirow{2}{*}{$\begin{array}{c}\text { Obser- } \\
\text { vation Points }\end{array}$} & \multicolumn{3}{|c|}{ Fraction } \\
\hline & $\begin{array}{c}\text { Sand } \\
(\%)\end{array}$ & $\begin{array}{l}\text { Silt } \\
(\%)\end{array}$ & $\begin{array}{c}\text { Clay } \\
(\%)\end{array}$ \\
\hline 1 & 29.65 & 41.44 & 28.91 \\
\hline 2 & 71.27 & 24.35 & 4.38 \\
\hline 3 & 71.40 & 16.23 & 12.37 \\
\hline 4 & 78.48 & 18.87 & 2.65 \\
\hline 5 & 37.25 & 26.43 & 36.32 \\
\hline 6 & 26.81 & 42.58 & 30.61 \\
\hline
\end{tabular}

The characteristic of Lake Beratan sediment is that it has the total organic matter content ranging from $12.6 \%$ to $19.6 \%$, showing a medium to high range. The total organic matter content in sediment can characterize the lake fertility. According to Entz (1977) <17\% total organic matter content (sediment dry weight) shows an oligotrophy type, while $>30 \%$ total organic matter content characterizes a eutrophy type. Based on that criterion, Lake Beratan is generally in oligotrophic condition (samples 1, 2, 4, 5, and 6) up to mesotrophic condition (sample 3). The condition of the mesotrophic condition is in the fish farming using floating basket location (Figure 1).

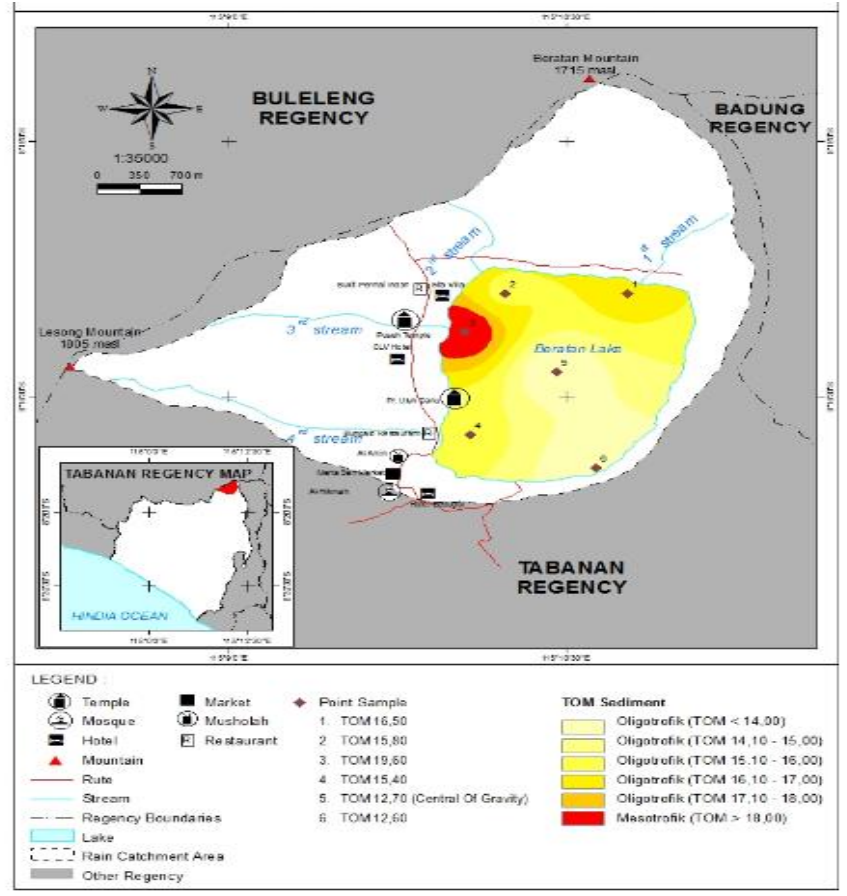

Fig. 1. Distribution of sediment TOM in Lake Beratan
The Lake Beratan sediment organic matter that tends to be high may originate from the inlet, the residue from water plant decomposition and feed waste and feases of the fish from the floating basket fish farming. The body of the lake that becomes the fish farming using floating basket, namely observation points $1,2,3$, and 4 have a higher total organic matter than that in observation points 5 and 6 which really do not have any fish farming using floating basket. This reflects the existence of a significant organic matter supply from the feed leftovers and fish feases of the farmed fish.

The organic carbon (c) and organic nitrogen ratio of the sediments reflect the fertility of the sediment system. According to Hakanson (1984), the $\mathrm{C} / \mathrm{N}$ organic ratio of the sediment should be taken into account as a means to estimate sediment productivity, in which the higher the $\mathrm{C} / \mathrm{N}$ sediment organic ratio the more the likelihood for the sediment to be oligotrophic.The problem is related to the extent of organic matter decomposition, the older it is the higher carbon content and the more difficult the decomposition is, then it cannot function as a source of feed. The $\mathrm{C} / \mathrm{N}$ organic ratio of waters can reach 50: 1, the proportion of the compound is high enough and come from the land and microfita increases, undergoing selective decomposition by microbes as long as the organic matter is transported by runoff (Wetzel, 1983; Walter et al., 2014).

Lake Beratan organic $\mathrm{C} / \mathrm{N}$ ratio seems to be relatively low (<20), indicating that the characteristics of organic sediment in the initial or young stage of decomposition.

\section{Benthos Community}

The result of the field observation in Lake Beratan aquatic ecosystem showed that there are 11 varieties of benthos, consisting of Mollusca, Diptera, and Oligochaeta (Figure 2). The the benthos community in Lake Beratan range from 284 to $3,409 \mathrm{ind} / \mathrm{m}^{2}$, indicating a medium abundance range.

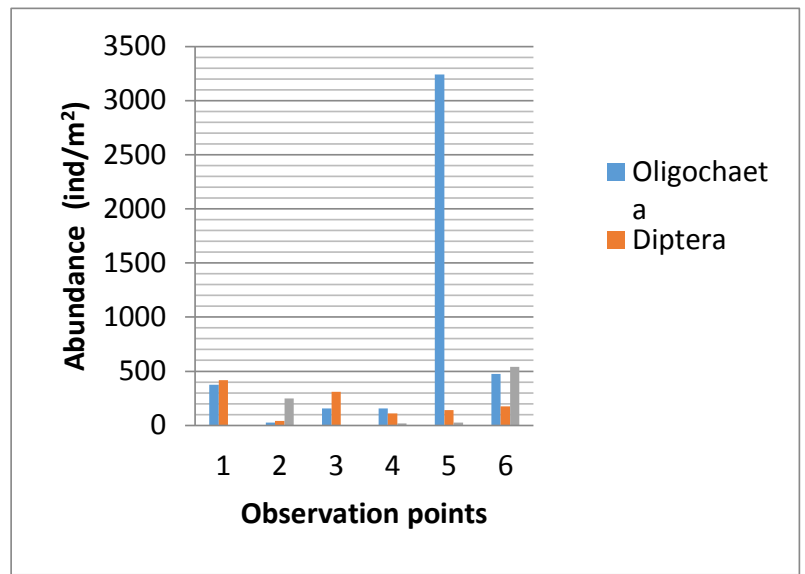

Fig. 2. Abundance Distribution of Benthos community classes in Lake Beratan

Oligochaeta class shows a high dominance in samples 5 and 6, while the lowest is in sample 2. Turbificidae is a group 
of benthos organism of the Oligochaeta class and Chironomid is the dominant group of Diptera class. Limnodrilus hoffmeisteri species is the principal element and seems to be very abundant, especially in sample 5 at $2792 \mathrm{ind} / \mathrm{m}^{2}$. Finally, another variety of Tubificidae is Branchiura Sowerby which is also found in sample 5 at $292 \mathrm{ind} / \mathrm{m}^{2}$.

Mollusca class is found especially of Gastropod group, namely Melanoides Tuberculata, Granifera and Thiara sp in samples 2, 4, 5, and 6 ranging from 17 to $542 \mathrm{ind} / \mathrm{m}^{2}$, while in samples 1 and 3 Gastropod group is not found.

\section{Relation between Sediment Organic Matter Content and Benthos Community}

Sediment organic matter content is one of the determinants of the presence of benthos community in a waters body., since it becomes a source of feed, but on the other hand, it will have an effect on the available oxygen content on the waters bed (Lukman,2003). In the condition in which there is enough oxygen for benthos community, benthos community is not affected by the low oxygen condition, thus the availability of organic matter can determine the level of abundance of benthos community. According to Lang (1997) and Mustapha (2011), the environmental factors that can have a role in the composition of benthos community are the quality and quantity of sediment total organic matter.

The high total organic matter content of Lake Beratan sediment caused the population of chironomid and tubificid groups dominate benthos community in the lake ( Figure 3).Tubificidgroup is the benthos community that lives in the water's sediment that undergoes the fertility of organic matter. The availability of organic matter becomes one ideal medium for it to dig a hole and to get its feed. The replacement of turbificidae community occurs parallel to the worsening of (Brinkhurst, 1972).

The result of statistical analysis showed that the correlation between Tubificid group abundance and the total organic matter in sediment and the sediment organic $\mathrm{C} / \mathrm{N}$ ratio in Lake Beratan is very small, both squarely and linearly, with a very small determination coefficient $\left(r^{2}<0.5\right)$.

On the basis of the correlation it seems that the relation between sediment organic $\mathrm{C} / \mathrm{N}$ ratio and Tubificidae abundance shows a squared relation pattern with the highest determination coefficient $\left(\mathrm{r}^{2}=0^{-147}\right)$. This is in line with the result of Lukman's study(2003) in Waduk Cirata inlet, that the abundance of Tubificidae group of Limnodrillus variety is influenced more by the condition of organic $\mathrm{C} / \mathrm{N}$ ratio than by sediment total organic matter.

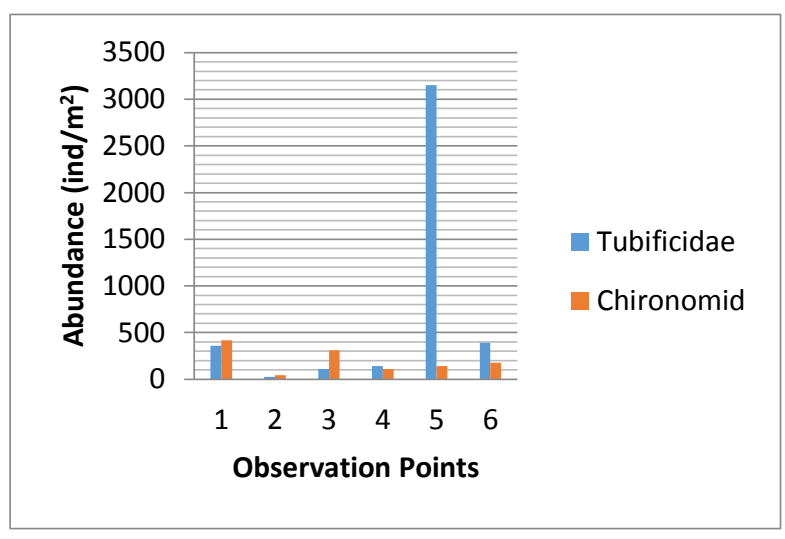

Fig. 3. Turbificid and Shironomid community Abundances in Lake Beratan

The abundance of Tubificid in sample 5 is high enough, with the domination of hoffineisteri species, assumed to be related to the low oxygen condition in the bottom substrate. Sample 5 is in the central of gravity of Lake Beratan, which every time supplies organic matter that is equivalent to the organic matter in the lake water column, so that the condition of the sediment makes it possible to be anorectic compared to other samples. According to Lang (1997) the abundance of Limnodrillus hoffineisteri follows the the high sediment organic matter content that supplies a source of feed , but this is not true with species that does not tolerate the low oxygen supply.

The relation between the abundance of Chironomid and sediment organic matter in Lake Beratan, both with the total organic matter and the sediment organic $\mathrm{C} / \mathrm{N}$ ratio is statistically very low, both linearly and squarely with a very small determination coefficient $\left(r^{2}<0,5\right)$. On the other hand, the pattern of relationship that is formed with the sediment total organic matter tends to be negative.

The presence of Chironomid community in Lake Beratan shows that the lake waters and its sediment column still contain dissolved oxygen. Chironomid generally grow in the waters that undergo organic pollution, but with more oxygenized condition and generally replaces Tubificidae community at a more oxygen content. This is because the resistance of Chironomid community toward the oxygen supply is low, less than that of the Tubificid community.

Mollusca community is only found in samples 2, 4, 5 and 6 and is not found in samples 1 and 3, namely the region with a relatively high organic matter $(>19 \%)$. Sample 6 that has the highest abundance turns out to have the lowest sediment total organic matter content (12.6\%). Mollusca community seems to prefer a region with well oxygenized with a low organic matter availability. The habitat that is preferred by Mollusca community, among others, has water flow with a medium speed, with sandy substrate with rocks. 


\section{CONCLUSION AND SUGGESTION}

The quality of Lake Beratan water is characterized by $\mathrm{pH}$ that tends to be base and the total organic matter content that is high, while the characteristics of the sediment are dominated by sand and silt fractions. The organic matter content shows oligotrophic to mesotrophic conditions with a relatively low organic $\mathrm{C} / \mathrm{N}$ ratio. Benthos community that is found consists of 11 varieties of benthos organism especially from Oligochaeta and Chironomid classes, the abundances ranging from 284 up to $3,409 \mathrm{ind} / \mathrm{m}^{2}$. Tubificidae and Chironomid are the dominant benthos organism. Tubificidae is from Oligochaeta class and Chironomid is from Diptera class.

\section{REFERENCES}

[1] Adnyana, I. W, (2013), "Pemantauan Perubahan Penggunaan Lahan di Kawasan Danau Beratan Provinsi Bali", Jurnal Bumi Lestari, 13(2), 8-12.

[2] Arsyad, S, (2012), "Konservasi Tanah dan Air dalam Penyelamatan Sumber Daya Air", Yayasan Pustaka Obor Indonesia.

[3] Brinkhurst, R. O, (1972), "Distribution and Abundance of Tubificid (Oligochaeta) Species in Toronto Harbour, Lake Ontario", J. Fish. Res. Bd. Can, 27, 1961-1969.

[4] Buchanan, J. B., \& Kain, J. M, (1984), Measurement of the Physical and Chemical Environment, In: N. A. Holme and A. D. Mc Intire (eds), Methods for The Study of Marine Benthos, IBP Handbook No. 16, International Biological Programme, Blackwell Scientific Publication, Oxford, 31-58.

[5] Entz, B, (1977), "Environmental Conditions of Percids Waters in Central Europe”, J. Fish. Res. Bd. Can, 34, 1586-1591.

[6] Grenberg, A. E., Clesceri, L. S., \& Eaton, A. D, (1992), "Standard Methods for the Examination of Waste Water", $18^{\text {th }}$ Edition, APHAAWWA-WEF.

[7] Hakanson, L, (1984), "On the Relation Between Lake Trophic Level and Lake Sediments", Wat. Res, 18, 303-314.

[8] Hehanussa, P. E, (2005), "Penataan Ruang dan Daya Dukung Sumber Daya Air di Dataran Tinggi Bedugul Provinsi Bali”, Prosiding Daya Dukung Sumber Daya Air, UPT Balai Konservasi Tumbuhan Kebun Raya Eka Karya Bali-LIPI bekerja sama dengan Badan Pengendalian Dampak Lingkungan Daerah Pemerintah Daerah Provinsi Bali.

[9] Hesse, P. R, (1971), “A Textbok of Soil Chemical Analysis”, Chemical Publ. Co., Inc, New York.

[10] Hidayat, A, (1988), "Method of Soil Chemical Analysis", Japan International Coorporation Agency (JICA) in the Frame Work of the Indonesia-Japan, Joint Food Crop Research Programme, Bogor.

[11] Lang, C, (1997), “Oligochaetes Organic Sedimentation, and Trophic State: How to Assess the Biological Recovery of Sediments in Lakes, Aquat", Sci, 59, 26-33.

[12] Lukman, (2003), "Peranan Kecepatan Arus dan Bahan Organik Sedimen Terhadap Biomassa Oligochaeta di Inlet Waduk Cirata, Limnotek, Perairan Darat Tropis di Indonesia", 9(1), 1-13.

[13] Mustapha, M. K, (2011), "Perspectives in The Limnology of Shallow Tropical African Reservoirs in Relation to Their Fish and Fisheries", The Journal of Transdisciplinary Environmental Studies, 10(1), 1-23. (www.journal-tes.dk/.../no\%203\%20Mustapha\%20).

[14] Pennak, R. W, (1978), "Freshwater Invertebrates of the United States", Second Edition, John Willey \& Sons, New York.

[15] Walter, F., Thierry, F., Emiliya. K., Andrea, L., Piero, G., André F. L. (2014), "A long-term multi-proxy record of varved sediments highlights climate-induced mixing-regime shift in a large hard-water lake $\sim 5000$ years ago". Journal of Limnology, 73(2), 211-222, eISSN 1723-8633. (http://www.jlimnol.it/index.php/jlimnol/article/download/jlimnol.2014 $.907 / 677)$

[16] Wetzel, R. G, (1983), "Limnology". Second Edition, W, B. Sauders College Publ, Philadelphia,7443 pp 